\title{
Plant Extracts used as Growth Promoters in Broilers
}

\begin{tabular}{l} 
Author(s) \\
\hline Barreto MSR' \\
Menten JFM"2 \\
Racanicci AMC \\
Pereira PWZ1 \\
Rizzo PV1 \\
1 Graduate students of the Animal Science \\
Department of Escola Superior de \\
Agricultura "Luiz de Queiroz", USP/ \\
Piracicaba. \\
2 Professor of the Animal Science \\
Department of Escola Superior de \\
Agricultura "Luiz de Queiroz", USP/ \\
Piracicaba. \\
3 Post-doc fellow of the Animal Science \\
Department of Escola Superior de \\
Agricultura "Luiz de Queiroz", USP/ \\
Piracicaba.
\end{tabular}

Mail Address

Escola Superior de Agricultura "Luiz de Queiroz"

Universidade de São Paulo

Departamento de Zootecnia - Setor Zootecnia de Não Ruminantes

Av.: Pádua Dias, 11. CP. 9

13.418-900. Piracicaba, SP, Brazil.

E-mail: marinasr@esalq.usp.br

\section{Keywords}

Apparent metabolizable energy, broilers, nutrition, growth promoters, plant extracts

\section{ABSTRACT}

Two experiments were carried out to assess the efficacy of plant extracts as alternatives for antimicrobial growth promoters in broiler diets. The performance experiment included 1,200 male broilers raised from 1 to 42 days of age. The metabolism experiment used 96 male broilers in the grower phase housed in metabolic cages for total excreta collection. At the end of the metabolism experiment, 24 birds were sacrificed to assess organ morphometrics. In both experiments, the following treatments were applied: control diet (CD); $C D+10 \mathrm{ppm}$ avilamycin; $C D+1000$ ppm oregano extract; $C D+1000$ ppm clove extract; $C D+1000$ ppm cinnamon extract; and $C D+1000$ ppm red pepper extract. The microencapsulated extracts contained $20 \%$ of essential oil. No significant differences $(P>0.05)$ in the studied performance parameters were observed among treatments. The dietary supplementation of the extracts did not influence $(P>0.05)$ nitrogencorrected apparent metabolizable energy values. In general, organ morphometrics was not affected by the experimental treatments, but birds fed the control diet had higher liver relative weight $(\mathrm{P}<0.05)$ as compared to those fed the diet containing red pepper extract, which presented the lowest liver relative weight. These results showed that there was no effect of the tested plant extracts on live performance or in organ morphometrics.

\section{INTRODUCTION}

Brazilian poultry production has continuously adopted new technologies (genetic improvement, nutrition, management, health control), which ensures its competitiveness in the global meat market. Production indexes of the domestic poultry production are similar or better than those obtained in any other country in the world (Butolo, 2005). Since the 1950s, antimicrobial feed additives (antibiotic and chemotherapeutic drugs) have been used as growth promoters, with generalized use in animal production, allowing adequate productivity of animals raised under intensive conditions (Menten, 2001).

Despite the observed improvement in broiler performance, the use of antibiotic growth promoters has been criticized due to its possible role in the occurrence of antimicrobial resistance in humans. Directive $1831 / 2003$ of the European Parliament, issued on Sept. 22 $2^{\text {nd }}, 2003$, determined the ban of the use of all antibiotics and chemotherapeutic drugs as growth promoters in the European Union as of Jan. $1^{\text {st }}, 2006$. This new context caused an increase in the search for alternative growth promoters.

In Europe, research on plant extracts as alternatives to the use of antibiotics as growth promoters has significantly increased, but in Brazil, this issue is rather new, and the number of studies is still small. 
Barreto MSR, Menten JFM, Racanicci AMC, Pereira PWZ, Rizzo PV

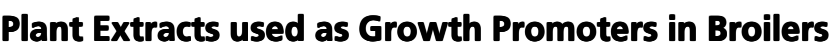

The most frequently studied plants to be used in animal nutrition today are (a) cinnamon, (b) cloves both appetite and digestion promoters, (c) oregano, which has antimicrobial properties, and (d) red pepper, which has antidiarrheal and anti-inflammatory potential (Kamel, 2000).

Plant active principles are chemical compounds present in the entire plant or in specific parts of the plant that confers them therapeutic activity or beneficial effects (Martins et al., 2000). These substances have low molecular weight and are derived from the plant secondary metabolism, including glucosides, alkaloids (alcohols, aldehydes, ketones, ethers, esthers, and lactones), phenolic and polyphenolic compounds (quinones, flavones, tannins, and coumarins), terpenoids (mono- and sesquiterpenoids, and steroids), saponins, mucilages, flavonoids, and essential oils (Martins et al., 2000; Huyghebaert, 2003). These compounds are produced by the plants for defense against external factors, such as physiological stress, environmental factors, and protection against predators and pathogens (Huyghebaert, 2003).

Essential oils are a group of active substances that are well-studied as growth promoters. These oils are complex mixtures of active components obtained by vaporization. The main difference between the terms "plant extracts" and "essential oils" is the method by which they are obtained or extracted. Despite being considered as plant extracts, they are obtained only by the method of steam extraction (Oetting, 2005).

The precise mode of action of essential oils is not fully elucidated yet, but some hypotheses have been raised: (1) pathogen control due to antimicrobial activity (Dorman \& Deans, 2000), (2) antioxidant activity (Hui, 1996), and (3) digestion enhancement (Brugalli, 2003) by stimulating enzyme activity.

The most commonly used methods to determine the antimicrobial activity of essential oils are diffusion in agar and dilution. The diffusion method uses a Whatman paper disk soaked with extract, and the antimicrobial potential of the oil is measured by the size of the inhibition zone of the studied microorganism, and the result is expressed as the diameter of the inhibition zone or in relative values. The results of the dilution method can be expressed as a percentage of microorganism inhibition as compared to a control treatment (with no essential oil) or, most frequently, as the minimum inhibitory concentration (MIC) of the essential oil required to inhibit the growth of a specific microorganism (Kalemba \& Kunicka, 2003). The determination of the antimicrobial activity of essential oils can be influenced by several factors: (1) if the oil has low solubility or high viscosity, its distribution on the culture medium is impaired; (2) long incubation periods may cause evaporation or breakdown of some components present in the oil during the test; (3) culture medium characteristics (type and volume); (4) inoculum (concentration and validity); (5) incubation temperature; and (6) type of dispersing agent or solvent (Kalemba \& Kunicka, 2003).

Table 1 shows MIC50 values of bacteriostatic efficiency of different plant extracts fed individually or in combination (Kamel, 2000). It is observed that the extracts present different patterns of antimicrobial activity and that, when fed in combination, they were more effective than the individual components.

Plant extracts and their secondary metabolites have dose-dependent bactericidal and bacteriostatic effects on microorganisms (bacteria, fungi, virus, and protozoa) (Smith-Palmer, 1998). According to Chao et al. (2000), Gram-negative bacteria tend to be less sensitive to essential oils than Gram-positive bacteria.

Most essential oils exert their antimicrobial effects by affecting bacterial cell wall, breaking down and coagulating proteins (Dorman \& Deans, 2000). These authors also suggest that cell walls are broken down by the lipophilic character of the essential oils that accumulate in the membranes. The external membrane of Gram-negative bacteria contains liposaccharides, forming a hydrophilic surface, creating a barrier to the permeability to hydrophobic substances, such as essential oils (Dorman \& Deans, 2000).

Brugalli (2000) asserted that, in practice, most plant extracts should be included in very high doses to promote the same bactericidal or bacteriostatic effect observed in vitro. Therefore, in vivo, the mode and the

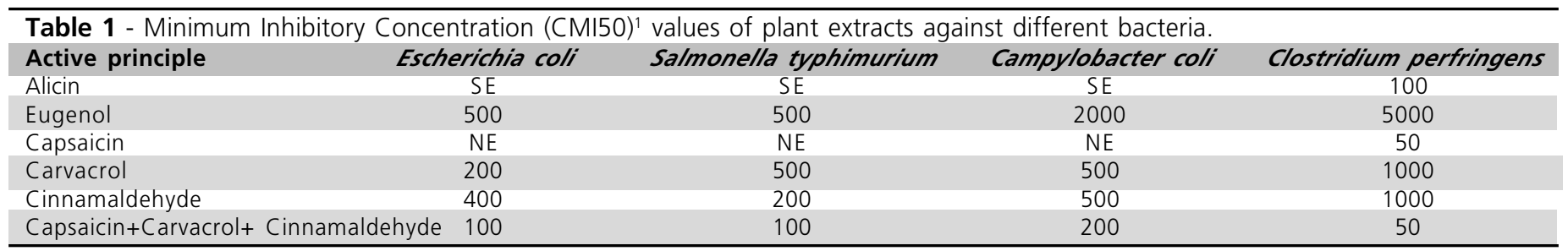

1- Values in ppm; NE= no effect. Source: adapted from Kamel (2000). 


\section{Barreto MSR, Menten JFM, Racanicci AMC, Pereira PWZ, Rizzo PV}

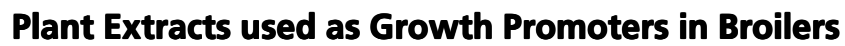

place of action of the active components of essential oils depend on their structure, metabolism, and inclusion level.

According to Kohlert et al. (2000), most active principles of plant extract are absorbed in the intestine by enterocytes, and readily metabolized by the body. The products of this metabolism are transformed into polar compounds by conjugation with glucoronate and excreted in the urine. As the active compounds are readily metabolized and have a short half life, the risk of tissue accumulation is probably minimal (Kohlert et al., 2000).

Although some effects have already been demonstrated, the mechanisms involved are still widely unknown. Further investigations on the action of the active principles and their effects in vivo are required. In addition, significant improvement of animal performance must be shown before plant extract are effectively adopted in animal nutrition.

This study aimed at evaluating the efficacy of cinnamon, clove, oregano, and red pepper plant extracts as alternatives to antimicrobial growth promoters in broiler diets.

\section{MATERIAL AND METHODS}

\section{Experiment 1 - Performance}

This experiment was carried out with 1.200 dayold male Cobb broilers purchased from a commercial hatchery, and housed in an experimental house from 1 to 42 days of age.

Birds were weighed and distributed in pens of 40 birds each in order to have the best uniformity in terms of average body weight.

Drinkers were cleaned, feed was distributed, and mortality was recorded daily. Birds and feeders were weighed weekly to determine body weight, weight gain, feed intake, and feed conversion ratio.

The starter feed was fed from $1-20$ days, the grower feed from 21 to 34 days, and the finisher feed from 35 to 42 days. Feeds were changed on the same day birds were weighed.

Plant extracts were used as essential oils, as they presented consistent composition (Givaudan do Brasil Ltda., Av. Eng ${ }^{\circ}$ Billings, 2185, Jaguaré, São Paulo - SP). As essential oils are volatile, they were submitted to microencapsulation, which consists in introducing the oils into an organic matrix to allow their preservation up to consumption.

The experimental treatments consisted of a nonsupplemented control diet (Treat. 1); a diet supplemented with $10 \mathrm{ppm}$ avilamycin (Treat. 2), and diets with the individual addition of $1000 \mathrm{ppm}$ of microencapsulated plant extracts containing $20 \%$ of the respective essential oil: cinnamon - cinnamaldehyde (Treat. 3); clove - eugenol (Treat. 4); oregano carvacrol (Treat. 5), and red pepper - capsaicin (Treat. 6).

Feeds were offered ad libitum during the entire experimental period in the mash form, and formulated with corn and soybean meal according to the nutritional levels recommended by Rostagno et al. (2005). The treatment additives were added to the basal diet replacing inert material (Table 2 ).

\begin{tabular}{|c|c|c|c|}
\hline Ingredients & Starter & Grower & Finisher \\
\hline Corn & 56.024 & 58.334 & 60.900 \\
\hline Soybean meal $46 \%$ & 35.982 & 33.255 & 30.780 \\
\hline Soybean oil & 3.490 & 4.640 & 4.884 \\
\hline Dicalcium phosphate & 1.833 & 1.684 & 1.524 \\
\hline Limestone & 0.888 & 0.839 & 0.794 \\
\hline Salt & 0.490 & 0.465 & 0.439 \\
\hline L-Lysine $\mathrm{HCl} 78 \%$ & 0.198 & 0.166 & 0.175 \\
\hline DL-Methionine $99 \%$ & 0.266 & 0.237 & 0.220 \\
\hline L- Threonine $98.5 \%$ & 0.059 & 0.035 & 0.034 \\
\hline Choline chloride $60 \%$ & 0.080 & 0.060 & 0.040 \\
\hline Vitamin supplement $^{1}$ & 0.100 & 0.080 & 0.060 \\
\hline Mineral supplement ${ }^{2}$ & 0.050 & 0.050 & 0.050 \\
\hline Anticoccidial $^{3}$ & 0.044 & 0.055 & \\
\hline Inert (sand) & 0.100 & 0.100 & 0.100 \\
\hline \multicolumn{4}{|l|}{ Calculated composition } \\
\hline ME (kcal/kg) & 3,050 & 3,150 & 3,200 \\
\hline CP $(\%)$ & 21.350 & 20.210 & 19.290 \\
\hline Dig. Methionine + Cystine (\%) & 0.844 & 0.791 & 0.755 \\
\hline Dig. Methionine (\%) & 0.560 & 0.519 & 0.492 \\
\hline Dig. Lysine (\%) & 1.189 & 1.099 & 1.048 \\
\hline Dig. Threonine (\%) & 0.773 & 0.714 & 0.681 \\
\hline Avail. phosphorus (\%) & 0.449 & 0.418 & 0.386 \\
\hline Calcium (\%) & 0.899 & 0.837 & 0.775 \\
\hline \multicolumn{4}{|c|}{ 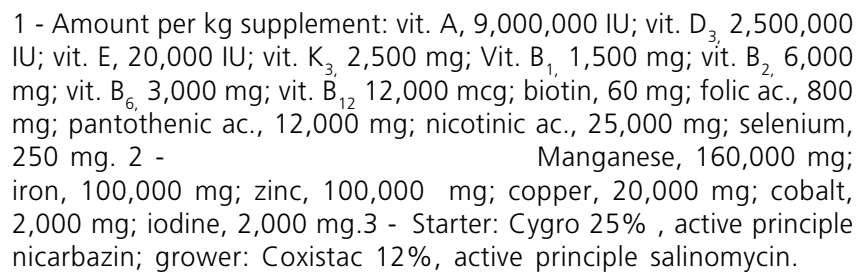 } \\
\hline
\end{tabular}

A randomized block experimental design, with six treatments and five replicates, was used. The following parameters were determined: live weight, weight gain, feed intake, feed conversion ratio (corrected for mortality), and mortality. Results were submitted to analysis of variance using PROC GLM (General Linear Models) of SAS (Statistical Analysis System, 2001), and means were compared by the test of Tukey at $5 \%$ de significance. 


\section{Barreto MSR, Menten JFM, Racanicci AMC, Pereira PWZ, Rizzo PV}

\section{Experiment 2 - Metabolism and morphometrics}

In this metabolism assay, 200 broiler chicks were housed in six adjacent pens in the same house and submitted to the same management as chicks from Experiment 1 . At 28 days of age, 96 birds were transferred to a metabolism room, and housed in 24 metal cages ( 4 birds per cage), with 16 birds per treatment.

The birds receive the same diet, corresponding to the experimental treatment, for the entire experimental period. Nitrogen-corrected apparent metabolizable energy values balance (AMEn) of the diets were determined using the method of total excreta collection (Matterson et al., 1965).

Birds were offered feed and water ad libitum, and received $24 \mathrm{~h}$ of light per day. After a period of 3 days of habituation to the facilities, excreta were collected for 4 days. In order to precisely determine the beginning and the end of the collection period, 1\% ferric oxide was added as marker in the feeds corresponding to the first collection and after the last collection. During this period, feed intake of every experimental unit was monitored in order to prevent feed waste and excreta contamination.

Excreta was collected from the trays twice daily, placed in plastic bags, and immediately placed in a freezer at $-18^{\circ} \mathrm{C}$. At the end of the experiment, excreta were weighed, thawed, homogenized, and the samples were pre-dried in a forced-air circulation oven at 65 ${ }^{\circ} \mathrm{C}$ for 72 hours. Gross energy of the ground diet and excreta samples was determined in a calorimetric bomb (model Parr 1261). Nitrogen and humidity contents were determined by combustion in a Leco automatic device (model FP-528). All determinations were carried out in triplicate.

The experimental treatments consisted of the same feeds fed during the grower phase in Experiment 1. A completely randomized experimental design, with six treatments of four replicates (24 experimental units) of four 28-day-old male broilers each was applied, with a total of 96 birds.

Feed intake and excreta produced by each experimental unit were used to calculate AMEn values.

AMEn values were submitted to analysis of variance using PROC GLM (General Linear Models) of SAS (Statistical Analysis System, 2001), and means were compared by the test of Tukey at $5 \%$ of significance.

For morphometrics, one 35-day-old bird per metabolic cage was randomly chosen, weighed, and sacrificed, in a total of four replicates per treatment.
After sacrifice, digestive (empty proventriculus, empty gizzard, pancreas, liver, and empty small intestine, ceca, and colon) and non-digestive (spleen and heart) organs were removed and weighed. Small intestine length was measured. Organ weights were expressed as a percentage of live weight as measured immediately before sacrifice.

Data were analyzed as in the metabolism assay.

\section{RESULTS AND DISCUSSION}

\section{Performance}

Average live weight, feed intake, and feed conversion ratio relative to the periods of 1-21 and 142 days are shown in Tables 3 and 4 , respectively. The absence of significant treatment effects, including of the treatment with antibiotic growth promoter, indicates the lack of microbiological challenge or inactivity of the added substances or doses. Since antimicrobials started to be used as growth promoters, researchers (Coates et al., 1952; Whitehair \& Thompson, 1956) working with broilers and swine, respectively, understood that the presence of an important health challenge in the field was essential to reveal the significant effects of these products on animal performance.

\begin{tabular}{|c|c|c|c|}
\hline \multicolumn{4}{|c|}{$\begin{array}{l}\text { Table } 3 \text { - Average live weight (LW), average feed intake (FI), and } \\
\text { feed conversion ratio (FCR) of } 1 \text { to } 21 \text {-day-old broilers. }\end{array}$} \\
\hline Treatments & LW (g) & FI (g) & FCR (g/g) \\
\hline Control & 996 & 1,248 & 1.310 \\
\hline Avilamycin & 992 & 1,220 & 1.287 \\
\hline Cinnamon & 995 & 1,235 & 1.299 \\
\hline Clove & 987 & 1,248 & 1.323 \\
\hline Oregano & 984 & 1,235 & 1.313 \\
\hline Red pepper & & 957 & 1,179 \\
\hline 1.291 & & & \\
\hline CV (\%) & 2.12 & 3.43 & 2.74 \\
\hline
\end{tabular}

\begin{tabular}{|c|c|c|c|c|}
\hline Treatments & LW (g) & $\mathrm{FI}(\mathrm{g})$ & FCR $(g / g)$ & MO (\%) \\
\hline Control & 3,039 & 4,559 & 1.521 & 0.80 \\
\hline Avilamycin & 3,046 & 4,529 & 1.509 & 0.40 \\
\hline Cinnamon & 3,079 & 4,622 & 1.523 & 0.40 \\
\hline Clove & 3,012 & 4,530 & 1.526 & 2.00 \\
\hline Oregano & 3,071 & 4,572 & 1.510 & 2.00 \\
\hline Red pepper & 3,028 & 4,572 & 1.532 & 0.60 \\
\hline CV (\%) & 2.05 & 2.77 & 1.48 & 96.6 \\
\hline
\end{tabular}

Some experiments with broilers (Boutsoglou et al., 2002; Cross et al., 2003; Demir et al., 2003; Lee et al., 2003a, 2003b; Hernández et al., 2004) also did not find statistical differences in the performance 
Barreto MSR, Menten JFM, Racanicci AMC, Pereira PWZ, Rizzo PV
Plant Extracts used as Growth Promoters in Broilers parameters of birds fed diets supplemented with different types, concentrations, or combinations of plant extracts. According to Lee et al. (2003a), the absence of effect on bird performance may be related to the composition of the basal diet and/or to the environmental conditions of the experiment. Feeds containing highly digestible ingredients limit the proliferation of bacteria in the intestinal tract because no substrate is left for bacterial growth, thereby reducing the antimicrobial potential of plant extracts (Lee et al., 2003a). The same thing is observed when birds are raised under low immune challenge conditions or strict health control. Freitas et al. (2001) did not observe significant differences in the performance of 24-day-old broilers fed garlic or antibiotics, and attributed these results to the low health challenge to which birds were exposed. Likewise, Fukayama et al. (2005) did not find any significant effect of feeds containing different oregano levels on the performance parameters of broilers up to 42 days of age.

It must be considered that, according to some authors (Langhout, 2000; Manzanilla et al., 2004), better results may be obtained when combinations of essential oils extracted from different plants, enriched by the addition of the more relevant active principles, are supplied. In the present experiment, the treatments with plant extracts did not include combinations of different plants, as the aim was to investigate which of the selected extracts (cinnamon, clove, oregano, or red pepper) would present better or worse results, and then carry out further trials with the best combinations of these extracts. In addition, we decided not to include more relevant active principles because these are synthetically produced. These may have been some of the factors that hindered the observation of possible benefits of the tested plant extracts on performance. Broilers fed a combination of essential oils (capsaicin, carvacrol, and cinnamaldehyde) showed higher weight gain (625 vs. $578 \mathrm{~g}$ ) and better feed conversion ratio (1.44 vs. 1.56) than birds fed the control diet (Jamroz et al., 2002). According to those authors, the addition of plant extracts increased feed ingredient digestibility.

As to the lack of effect of the treatments applied in the present experiments, it is important to consider the dose of the tested active principles. Each microencapsulated extract was formulated with $20 \%$ of the essential oil, which contained the tested active principle. These active substances are not usually found in their pure state, but as complexes, which components complete each other and enhance their action on the body. According to Cechinel Filho and Yunes (1998), the chemical composition of plants is considerably different in its different parts, and it is influenced by environmental factors, such as climate, soil, and harvest time. Therefore, the challenge when using plant extracts is to identify and to quantify the effects exerted by the different components present in the essential oils on the body. Therefore, we are not able to precisely assert the amount of active principle that was given to the birds, only that it was lower or equivalent, at the most, to $200 \mathrm{ppm}$, which is the total amount of essential oil present in each treatment.

These considerations allowed us to compare the dose used in our experiment with the Minimum Inhibitory Concentration (MIC50) values proposed by Kamel (2000) in Table 1. According to the data presented in that table, MIC50 values of most plant extracts used in those experiments are higher than 200 ppm, which may explain the lack of significant effect of our treatments on performance. Also according to the table, capsaicin (red pepper) does not present bacteriostatic effect against Escherichia coli, Salmonella typhimurium, or Campylobacter coli, but only against Clostridium perfringens with a MIC50 value of 50 ppm, lower than that supplied in our experiments. On the other hand, carvacrol (oregano) has a MIC50 value of 200 ppm against Escherichia coli and a much higher value - over 500 ppm - against the other bacteria. As for cinnamaldehyde (cinnamon) presents a MIC50 value of 200 ppm against Salmonella typhimurium, and equal to or higher than 400 ppm for the other microorganisms, whereas eugenol (clove) is the only substance with MIC50 values much higher than 200 ppm - between 500 and 5000 ppm for all bacteria considered in Table 1.

Based on this information, it is possible that the 200 ppm dose of essential oil supplied was not sufficient to reach the MIC50 values of the active principles against most bacteria that are relevant in broiler production.

\section{Dietary metabolizable energy}

There was not significant effect $(P>0.05)$ of the evaluated treatments on AMEn of the experimental diets (Table 5). This may be attributed to the supply of highly digestible diets, and therefore a further increase in nutrient digestibility would be virtually undetectable (Lee et al., 2003b).

Mean ( \pm standard deviation) AMEn of the grower feed of the six treatments was 3,163 $\pm 0,027 \mathrm{kcal} / \mathrm{g}$, which is very similar to the calculated value of 3,150 $\mathrm{kcal} / \mathrm{g}$ (Table 2). 


\section{Barreto MSR, Menten JFM, Racanicci AMC, Pereira PWZ, Rizzo PV}

\begin{tabular}{cc}
\hline $\begin{array}{c}\text { Table } \mathbf{5} \text { - } \\
\text { (AMEn) of feeds supplemented with different plant extracts. } \\
\text { Treatments }\end{array}$ & Mean AMEn (kcal/g) \\
Control & 3,171 \\
Avilamycin & 3,123 \\
Cinnamon & 3,203 \\
Clove & 3,157 \\
Oregano & 3,146 \\
Red pepper & 3,176 \\
CV $(\%)$ & 0,86 \\
\hline
\end{tabular}

\section{Organ morphometrics}

Table 6 shows relative weight means (as a percentage of live weight at slaughter) of digestive and non-digestive organs, and absolute small intestine length as a function of treatments.

There was a significant difference in liver relative weight between the control and the red pepper treatments $(P<0.05)$. Birds fed the control diet presented significantly heavier livers as compared to those fed the diet with red pepper extract, which was the lowest (1.80 vs. $1.56 \%$ ) among all treatments. All other parameters did not present any significant difference $(P>0.05)$ among treatments. These results are consistent with those observed by Hernández et al. (2004), who did not find differences among the control treatment and those containing antibiotic or mixtures of plant extracts for organ weight of 42-dayold broilers.

\section{CONCLUSIONS}

Cinnamon, clove, oregano, and red pepper extracts individually added to broiler feeds at $200 \mathrm{mg} / \mathrm{kg}$ did not influence broiler performance, and neither the supplementation of $10 \mathrm{mg}$ of the antibiotic avilamycin per $\mathrm{kg}$ of feed. Also, there was no indication of an enhancement of energy use promoted by the tested additives.

\section{REFERENCES}

Botsoglou NA, Florou-Panari P, Christaki E, Fletouris DJ, Spais AB. Effect of dietary oregano essential oil on performance of chickens and on iron-induced lipid oxidation of breast, thigh and abdominal fat tissues. British Poultry Science 2002; 43:223-230.

Brugalli I. Alimentação alternativa: a utilização de fitoterápicos ou nutracêuticos como moduladores da imunidade e desempenho animal. Anais do Simposio sobre Manejo e Nutrição de Aves e Suínos; 2003; Campinas, São Paulo. Brasil. Campinas: CBNA; 2003. p.167-182.

Butolo JE, Butolo EAF. Avaliação do "Folhelho Mineral" como "cama" na criação de frangos de corte. Anais do Simposio sobre Nutrição de Aves e Suínos; 2005; Cascavel, Paraná. Brasil. Cascavel: CBNA; 2005. p.205-230.

Cechinel Filho V,Yunes RA. "Estratégias para obtenção de compostos farmacologicamente ativos a partir de plantas medicinais. onceitos sobre modificação estrutural para otimização da atividade". Química Nova 1998; 21(1):99-105

Chao SC, Young DG, Oberg CJ. Screening for inhibitory activity of essential oils on selected bacteria, fungi and viruses. Journal of Essential Oil Research 2000; 12:639-649.

Coates ME, Dickinson CD, Harrison GF, Kon SK, Porter JWG, Cummins $\mathrm{SH}$, Cuthbertson WFJ. A mode of action of antibiotics in chick nutrition. Journal of the Science of Food and Agriculture 1952; 3:43-48

Cross DE, Svoboda K, Mcdevitt RM. et al. The performance of chickens feed diets with and without thyme oil and enzymes. British Poultry Science 2003; 44:S18-S19.

Demir E, Sarica S, Özcan MA. et al. The use of natural feed additives as alternative for an antibiotic growth promoter in broiler diets. British Poultry Science 2003; 44:44-45.

Dorman HJD, Deans SG. Antimicrobial agents from plants: antibacterial activity of plant volatile oils. Journal of Applied Microbiology200; 88:308-316.

European Union. Regulation (EC) No $1831 / 2003$ of the European

\begin{tabular}{|c|c|c|c|c|c|c|c|}
\hline \multirow[b]{2}{*}{ Organ } & \multicolumn{6}{|c|}{ Treatments } & \multirow[b]{2}{*}{ CV (\%) } \\
\hline & Control & Avilamycin & Cinnamon & Clove & Oregano & Chili & \\
\hline Proventriculus. \% & 0.34 & $0.35^{\circ}$ & 0.35 & 0.37 & 0.33 & 0.31 & 14.14 \\
\hline Gizzard. \% & 2.23 & 2.11 & 2.30 & 2.26 & 2.12 & 2.19 & 8.18 \\
\hline Pancreas. \% & 0.18 & 0.20 & 0.21 & 0.21 & 0.22 & 0.20 & 10.67 \\
\hline Liver. \% & $1.80^{a}$ & $1.72^{\mathrm{ab}}$ & $1.61^{\mathrm{ab}}$ & $1.68^{\mathrm{ab}}$ & $1.62^{\mathrm{ab}}$ & $1.56^{b}$ & 9.16 \\
\hline Empty small intestine. \% & 2.58 & 2.75 & 2.64 & 2.81 & 2.61 & 2.74 & 13.99 \\
\hline Empty large intestine. \% & 0.69 & 0.69 & 0.75 & 0.68 & 0.68 & 0.63 & 20.11 \\
\hline SI length. m & 1.63 & 1.62 & 1.58 & 1.60 & 1.47 & 1.65 & 7.87 \\
\hline Heart. \% & 0.59 & 0.54 & 0.55 & 0.58 & 0.53 & 0.58 & 13.29 \\
\hline Spleen. \% & 0.10 & 0.10 & 0.10 & 0.09 & 0.10 & 0.11 & 26.81 \\
\hline
\end{tabular}

$a, b$ - Values followed by the same letter are not different $(P>0.05)$. 


\section{Barreto MSR, Menten JFM, Racanicci AMC, Pereira PWZ, Rizzo PV}

Plant Extracts used as Growth Promoters in Broilers
Parliament and of the Council of 22 september 2003 on additives for use in animal nutrition [cited 2008 jun 6]. Available from: http:/ /europa.eu/scadplus/leg/en/lvb/112037d.htm\#AMENDINGACT

Freitas R, Fonseca JB. et al. Utilização do alho (Allium sativum L.) como promotor de crescimento de frangos de corte. Revista da Sociedade Brasileira de Zootecnia 2001; 30(3):761-765.

Fukayama EH, Bertechini AG, Geraldo A. et al. Extrato de orégano como aditivo em rações para frangos de corte. Revista da Sociedade Brasileira de Zootecnia 2005; 34(6):2316-2326.

Hernandez F, MadridJ, Garcia V, Orengo J, Megias MD. Influence of two plant extracts on broilers performance, digestibility and digestive organ size. Poultry Science 2004; 83:169-174.

Hui YH. Oleoresins and essential oils. In: Hui YH, editor. Bailey's industrial oil and fat products. New York: Wiley-Interscience Publication; 1996 cap.6, p.145-153.

Huyghebaert G. Replacement of antibiotics in poultry. Proceedings of the Eastern Nutrition Conference; 2003; Quebec. Canada. Quebec: UON; 2003.

Jamroz D, Kamel C. Plant extract enhance broiler performance. Journal of Animal Science 2002; 80(suppl.1):41.

Kalemba D, Kunicka A. Antibacterial and antifungal properties of essential oils. Current Medicinal Chemistry 2003; 10:813-829.

Kamel C. A novel look at a classic approach of plant extracts. Feed Mix- The International Journal on Feed, Nutrition and Technology 2000; 9(6):19-24.

Kohlert C, Van Rensen I, Marz R, Schindler G, Graefe EU, Veit M. Bioavailability and pharmokinetics of natural volatile terpenes in animal and humans. Planta Medica 2000; 66:495-505.

Langhout P. New additives for broiler chickens. Feed Mix 2000; 18(6):24-27.

Lee KW, Everts H, Kappert HJ. et al. Effects of dietary essential oil components on growth performance, digestive enzymes and lipid metabolism in female broiler chickens. British Poultry Science 2003a; 44(3):450-457.

Lee KW, Everts H, Kappert HJ. et al. Dietary carvacrol lowers body weight but improves feed conversion in female broiler chickens. Journal of Applied Poultry Research 2003b; 12:394-399.

Manzanilla EG, Perez JF, Kamel C. et al. Effect of plant extracts and formic acid on the intestinal equilibrium of early-weaned pigs. Journal of Animal Science 2004; 82(Supl. 1):3210-3218.

Martins ER, Castro DM, Castellani DC, Dias JE. Plantas medicinais. Viçosa, MG: UFV; 2000.

Matterson LD, Potter LM, Stutz MW. et al. The metabolizable energy of feed ingredients for chickens. Storrs: University of Connecticut, Agricultural Experiment Station Research Report ; 1965. v.7.

Menten JFM. Aditivos alternativos na produção de aves: probióticos e prebióticos. Anais da Reunião Anual da Sociedade Brasileira de Zootecnia; 2001; Piracicaba, São Paulo. Brasil. Piracicaba: ESALQ/ USP; 2001. p.141-157.

Oetting LL. Extratos vegetais como promotores do crescimento de leitões recém-desmamados [tese]. Piracicaba (SP): Escola Superior de Agricultura "Luiz de Queiroz"; 2005.

Penz AMJ, Kessler AM, Brugali I. Novos conceitos de energia para aves. Anais do Simpósio Internacional Sobre Nutrição de Aves; 1999; Campinas, São Paulo. Brasil. Campinas: Facta;1999.

Rostagno HS, Albino LFT, Donzele JL, Gomes PC, Ferreira AS, Oliveira RF, Lopes DC. Tables brasileiras para aves e suínos: composição de alimentos e exigências nutricionais. 2.ed. Viçosa (MG): Universidade Federal de Viçosa; 2005.

Smith-Palmer A, Stewart J, Fyfe L. Antimicrobial properties of plant essential oils and essences against five import food-borne pathogens. Letters in Applied Microbiology1 1998; 26:118-122.

Whitehair CK, Thompson CM. Observations in raising "diseasefree" swine. Journal of the American Veterinary Medical Association 1956; 128:94-98 